\title{
Erratum to: Distribution of Boron Between Silicon and $\mathrm{CaO}-\mathrm{MgO}-\mathrm{Al}_{2} \mathrm{O}_{3}-\mathrm{SiO}_{2}$ Slags
}

\author{
LARS KLEMET JAKOBSSON and MERETE TANGSTAD
}

DOI: $10.1007 / \mathrm{s} 11663-014-0224-7$

(C) The Minerals, Metals \& Materials Society and ASM International 2014

\section{Erratum to: METALLURGICAL AND MATERIALS TRANSACTIONS B DOI: 10.1007/s11663-014-0088-x}

IN the article, an incorrect procedure was given for the preparation of the glass disks analyzed by XRF. The correct procedure is given as follows. The glass disks were made with $0.5 \mathrm{~g}$ sampled slag and a $5.0 \mathrm{~g}$ mixture of 34 pct lithium metaborate and 66 pct lithium tetraborate.
It was explained in the article that approximately 100 to $140 \mathrm{mg} / \mathrm{kg}$ boron was added as pure $\mathrm{B}_{2} \mathrm{O}_{3}$ to two of the master slags. For these two slags it may be clarified that the binary 50 pet $\mathrm{CaO}-50$ pet $\mathrm{SiO}_{2}$ master slag was used for a single experiment labeled FS5 in Table II while the ternary $\mathrm{MgO}-\mathrm{Al}_{2} \mathrm{O}_{3}-\mathrm{SiO}_{2}$ master slag was used for all the experiments given in Table VII except the experiment labeled MAS4.

LARS KLEMET JAKOBSSON, Postdoctoral Research Fellow, and MERETE TANGSTAD, Professor, are with the Department of Materials Science and Engineering, Norwegian University of Science and Technology, Trondheim, Norway. Contact e-mail: lars.k.jakobsson@ ntnu.no

The online version of the original article can be found under doi: 10.1007/s11663-014-0088-x.

Article published online November 1, 2014. 